\title{
Geographical analysis of ecology-dependent diseases of Kryvyi Rih population in order to provide a sustainable development of the industrial regions
}

\author{
Daria Shiyan*, Iryna Ostapchuk, and Olena Lakomova \\ Kryvyi Rih State Pedagogical University, 54 Gagarina Ave., Kryvyi Rih, 50086, Ukraine
}

\begin{abstract}
The geographical, ecological and territorial peculiarities of the dynamics and the appearance's reasons of the population's sick rate in dependence on the environment's state of Kryvyi Rih town with the aim of the stable development's provision of the industrial regions. The influence of the contamination's sources on the health state of the Kryvyi Rih population is cleared up and the space-time peculiarities of the sick rate's display are established: the influence of the environmental risks' factors on the population's sick rate and the display of the diseases' separate groups are defined, estimated and mapped, the spreading's indicators of the ecologically dependent pathology from the distance to the stationary sources of pollution and from the factors of the environmental risks are revealed. The statistical base is created and the factors' analysis of the environmental risks, the sick rate, the main demographical indicators of Kryvyi Rih population for the period of 2004 - 2019 is made and it's determined that the sick rate and the mortality, caused by it, play the essential role in the development of the demographical situation of Kryvyi Rih town.
\end{abstract}

\section{Introduction}

The peculiarities of the geographical research of the problem of the population's sick rate and its dependence on the display of the environmental risk in the limits of the definite territories are examined in the article. This problem is the geographical - spatial one, because the space-time run of the different types of diseases has the complex character, therefore it's investigated with the help of the geographical scientific methods. The geographical approaches permit also to reveal more efficiently (in comparison with the other sciences) the space-time independence between the appearance of the diseases and the specificity of the municipal environment. In particular, the process of spreading of the ecologically-dependent sick rate in the geographical space is described best of all by the model, according to which the ecologically-dependent diseases are spread from the centers of the environment's contamination, losing its activity from the center to the outlying area.

In contrast to the traditional medical-geographic zoning, the necessity to conduct the ecological-geopathogenesis zoning of the territories, on which the definite types of the population's diseases are developed, is proved. For example, the geo-spatial run of the population's sick rate in the industrial regions (Kryvyi Rih) and the separation of the regions with the different level of the environmental risk present the additional proofs, concerning the dependence of the internalmunicipal spatial specificity of all the geographical processes and phenomena on the unique configuration and the specific geographical position of the town.
The problems of the population's sick rate interest the geographers for a long time. Such an interest is not accidental, because the geographic or the spatial specificity of these problems has always been so bright that it didn't remain any doubts, concerning the subject field of science, which has to solve them. However, if, except the medics $[1,2,3]$, the representatives of the natural-geographic sciences were engaged in these problems, in particular, the bio-geographers $[4,5]$ not so long ago, then, the geographical [6-8] and the ecological approaches [9] become more and more actual lately in many publications. Due to this, the problems' studying process of the geographical peculiarities of the ecologically-dependent diseases' formation at the higher educational establishments gains the special actuality.

\section{Literature review}

Considering it necessary to research the theoreticalmethodic turns of the ecologically-dependent diseases' problem, the authors made the analysis of the conducted theoretical and practical researches of the population's sick rate's problem and indicated the methodological landmarks strictly for the geographic sciences:

- the problem of the population's sick rate is almost not determined without the getting used to the space-time continuum. The first scientific researches in this direction didn't deal without the geographic maps [10]; - the spreading of the sick rates in the form of the epidemics, epizootics or epiphytes expresses the aspiration for the model "center-outlying area" [11],

* Corresponding author: shiyandv2017@gmail.com 
generally known in the geographic sciences, and still further - the theory of the innovations' diffusion of T. Hegerstrand $[12,13]$;

- the majority of the medical-geographic researches is connected with the natural centers of the diseases' appearance and uses the landscape-scientific approaches [14];

- the medical-geographic researches of the ecologicallydependent diseases (changes of the arterial pressure, the disease of the respiratory organs' systems, the urinarysexual system and others) are more frequently connected with the anthropologic-genetic changes of the environment (the contamination of the atmospheric air by dust and chemical combinations, the radio-active contamination, the influence of the electromagnetic artificial fields and noise on health) $[15,16]$;

- the joint task of the Medicine and Geography is the search of the ways of the optimal interaction between the individual, economy and environment, both as the natural one and as the one, created by him (her) [17], the same tasks are solved by the conception of the stable development $[18,19]$;

- the single conception of the non-zero or the accepted risk dominates at the present time, because the risk's level in any system cannot be equal to zero and it changes in the limits of the probability from 0 to 1 , where 0 is the probability of the absolute inertness (the event does not happen in any case), 1 is the risk is realized (the event has happened) [20];

- there is no distinct definition of the notions social, ecological, medical risk, the risk of the human diseases' appearance. There is the notion "environmental risk" [21] in the foreign publications as the risk for the human health in the result of changes of the environment's quality; there is the notion "risk factors in health and disease" [22], in which the ecological factors, influencing the health state of the individual and the appearance of the diseases, act as the separate component. The authors will come out of the most widely-used notion "environmental risk" in the presented research, which acts as the inter-discipline and complex notion and permits to make the research of the ecologically-dependent diseases of the Kryvyi Rih population and to elaborate the measures on the provision and control of the risks' high levels.

One general conclusion flows logically out of the points, mentioned above - the population's sick rate appears in the background of the complex interaction of the person with the environment's elements, where he (she) lives or works. And if the scientists were mostly interested in the natural components, being the objects of the investigation of the natural-geographic sciences [2325], of this environment till the middle of XX century, then, the main priorities of the latest decades are presented mainly to the social and techno-genetic environment, which are already the objects of the geographic sciences [26, 27]. At this, the ecology joined the subject sphere of the medical-geographical problems which has more right for the research of the interrelations of the organism and the environment. However, such its direction as the ecology of an individual is recognized among the medics-geographers as being "their own" $[28,29]$. Afterwards, you may state that the problem of the population's sick rate is also ecological.

The geographical peculiarities of the territories and their influence on the display of the population's ecologically-dependent diseases play the significant role from the view point of the stable development's conception. According to the results of the author's researches, the modern social-economic and medicalgeographical specificity of Kryvbas is much determined by the original territory's stretching form of Kryvyi Rih town. But such form is the direct result of the spatial localization of the ore body, at the processing of which the settlement boundary was formed. Afterwards, the geological structure of Kryvyi Rih town forms that fundament, on which the further social-geographic, ecologically-medical processes are developing [30].

Unfortunately, the modern geographic researches are conducted mainly in the narrow scientific spheres and they don't have the features of the complex and interdiscipline researches [28], but as far as the works, devoted to the "joint" directions, in particular, between the physical and the social geography, are concerned, they are the single ones [22]. To our mind, the very such "joint" is formed during the last decade in the scientific approaches to the problem's study of the population's sick rate. The works of the geologists, the biogeographers, the landscape scientists, the cartographers [29-32] appear still more and more frequently in the background of the great number of the investigations, conducted by the medics and presented mainly in the periodical publication "Environment and Health". The interest of the geographers to this problem grows more and more [8]. The legitimateness of such approaches' use is confirmed in the classical works on the diffusion of the innovations, where the spatial widening of the diseases is connected with the definite periods (stages) of the geographic space's focusing [13].

The foreign researchers also pay an attention to the problem's inter-discipline character of the appearance of the ecologically-dependent diseases and the environmental risk, among their number they separate such risk's factors: the behavioral, physiological, demographic, ecological, genetic ones [22], speak on the necessity to unite the efforts of geography, psychology, sociology, law, economics, the public policy in the researches of the social risks [33]. Thus, in our opinion, the very such multi-factuality and the inter-discipline should become the leading characteristic feature, positing the problem of the geographic research of the population's ecologically-caused diseases.

It's difficult to research such a complex scientific problem from the position of one science, which would take into account, if possibly, all the components of the system "nature-population-economy": climate, the geochemical background, the vegetable and animal world, the danger's degree of natural disasters, the level of the economic development, the social-political order [34]. Correspondingly, the necessity appears to use the ways, methods and modes of the tasks' solvation in physical geography, geology, geo-physics and other natural sciences. Each of them, in its turn, absorbs the 
knowledge's elements of the overlapping sciences, due to which gains the new results, necessary to reveal the regularities of the interaction of the nature and the society.

Such a complex approach to the problem's study of the people's sick rate started to develop actively on the land of the USA, beginning from 1980, when the ecological strategy of the state included the state management of the nature-use and the market mechanisms of its regulation. The very conception of the environmental risk has become the basis of the state ecological policy of the USA, according to the definition of the National Academy of Sciences of the USA, the estimation of the risk - is the use of the available scientific information and the scientifically-grounded forecasts for the arrangement of the influence's security of the harmful conditions and materials on human health [35]. At the same time, in the middle of the 80 -s of XX century, the researches of the natural risks started to be held under the leadership of the professor S. M. Myahkov at the geographic faculty of MSU (Russia), he founded the bases of the new scientific direction - "Geography of Natural Dangers and Risk" [36].

At this, the "way out" to the practical solvation of the problem in the research of the notion "environmental risk" is considered by the authors to become still more important. The risk's notion in the presented case is complex and it includes: the estimation of the ecological intention's sharpness of the definite geographical region, the level of the population's sick rate, dependence of the incidence of the population on the environmental situation and others.

It's hard to speak of the problem's research of the ecologically-dependent diseases without their relation to their spatial display and the determination of the spacetime causes by the factors of the environment. The formation of the complex component's and the medicalgeographical maps effects sufficiently the formation of the theoretical-methodological bases and the methodic ways in the medical-geographic researches, increases their meaning in the management's affair of the development and the territorial organization of health protection [37, 38].

The application's possibilities of GIS technologies at mapping of the ecologically-dependent diseases and the separation of the medical-geographical regions are important, their reflection on the map - is the result of the medical-geographic zoning, which reflects the objectively existing territorial dynamic systems, being similar enough on conditions of the social health formation [39].

The special relations in the middle of the medicalgeographical regions are formed between the inhabited localities and the landscapes, surrounding them: the definite resources are withdrawn out of the nature, but the different wastes, which can be involved into the natural cycles of the circulation and create the unfavorable conditions for the population's health, enter the natural complexes.

The number and the sizes of the inhabited localities increase with the development of the territory.
Sometimes the run of the processes acquires the reverse character in so-called the depressive regions - the number of the population becomes less; the agricultural fields are overgrown and others. The analysis of all the changes, happening in the structure of the medicalgeographical regions, permits to reveal the main regularities of their development and to create the medical-geographic forecasts on this basis [39].

The researches of the ecological problems have become more intensive for the last years, the medical geography began to develop qualitatively new approaches and methods for studying the incidence of the population. Therefore, the thought begins to widen among the geographers that the sick rate of the population may be considered to be the most sensitive indicator, characterizing the environment's influence on the person and vice versa [40, 41].

Properly, paying the attention to these new approaches, the authors formed the idea of the ecologically-dependent diseases [42], being confirmed in the other modern works too [16, 21, 43]. Thus, according to the opinion of O. P. Gavrylenko [40], there are such indicators among the negative indicators of ill-health, the spreading of which depends, to a certain extent, on the state of the environment. These diseases are called the ecologically-dependent [40]. The environment can also have the characteristic features, being strictly not pathogenic for the person, but during the interaction with them the potential danger for the person to have the disease grows. We call such an effect as being multiplicative, caused by the phenomenon of synergism, in our works $[20,42]$. This is the thing that causes the actuality of our research.

Basing on the analysis of the previously conducted researches in the sphere of the ecologically-caused diseases and the influence of the ecological factors on their appearance, the conducted researches of different types of risks, the grounded theoretical-methodological bases of the indicated problem, the authors investigated the geographical and ecological peculiarities of the dynamics and the reasons of appearance of the population's sick rate in dependence of the environment's state of Kryvyi Rih town. The analysis of the sick rate for the separate diseases on the territory of Kryvyi Rih, as the industrial town, is made with the help of the specialized data base in the environment GIS MapInfo Professional. The territorial peculiarities of the population's sick rate of the industrial region are researched in the work, the classification of the Kryvyi Rih regions, according to the population's sick rate, is made, the ecological-geo-pathogenic zoning of the Kryvyi Rih territories is grounded and made on the basis of the investigation of the internal-regional peculiarities of the population's sick rate. The research results are introduced by the authors into the training process of the Geographic faculty's students and are included into the lecture-practical studies on the disciplines "GeoEcology", "Bases of Geo-Ecology", "Ecology and Ecological Tourism".

The influence of the contamination's sources on the population's health state of Kryvyi Rih town is cleared up and the space-time peculiarities of the sick rate's 
display are established (the influence of the environmental risks' factors on the population's sick rate is defined, estimated and mapped). The research is conducted at the Department of Physical Geography, Regional Ethnography and Tourism on the basis of the Kryvyi Rih State Pedagogical University by the collection and the statistical analysis of the factors' data of the environmental risks, the sick rate, the indicators of the birth-rate, mortality and natural increase of the Kryvyi Rih population in the period of 2004-2019. The factors of the environmental risks are estimated, the stable dependence of the ecologically-caused diseases on the pollution of the atmospheric air, the surface waters, the grounds is revealed, the statistical analysis of the population's sick rate is made and the ecologicallydependent diseases are mapped, the dependence's indicators of the ecologically- dependent pathology's spreading from the distant area to the stationary sources of contamination and on the factors of the environmental risks are revealed.

It's determined, that the very complex geographic researches of the population's sick rate acquire more and more importance on conditions of the stable development's provision of the industrial cities, because their display and results have the double character: from one side, they are caused by the ecological situation of the region and are the display's result of the ecological factors of different genesis ( the pollution of the atmosphere, the surface waters, grounds and others), from the other side, - they are the expression of the separate type of the environmental risks.

The geographical approach to the state's study of the population's sick rate for the ecologically-caused diseases of the industrial region, in dependence on the complex of the landscape, social-economic and ecological characteristic features of the separate territories, is improved.

\section{Methods}

The research is conducted with the use of the generalscientific ways and methods: the statistical-mathematical (for the estimation of the quantitative parameters of the population's sick rate with the ecologically-dependent diseases, the estimation of the ecological situation of Kryvyi Rih town and the contaminations from the stationary and movable sources, the estimation of the environmental risks' factors); the mathematical (for the calculation of the spreading's dependence indicators of the ecologically-dependent pathology from the distant area to the stationary sources of pollution); the systemstructural and the system-functional analysis (the research of the complex connections in the system "nature-population-economy", appearing in the development's process of the ecologically-dependent diseases in the industrial regions). The special ways and methods are used: the comparative-geographical analysis (the study of the territorial distinctions of spreading of the ecologically-dependent diseases, the dependence's determination of the ecologically-dependent diseases on the factors of the environmental risks); the historical- geographical analysis (the research of the space-time regularities of the display of the environmental risks and the ecologically-dependent diseases, the dynamics of the ecological situation, the sick rate, the birth-rate, mortality and the natural increase); the cartographical one (the realization of the territorial differentiation and the spatial analysis of the sick rate's appearance and spreading and the determination of the sick rate's dependence on the display of the environmental risks' factors in the limits of the definite territories, the realization of the medical-geographic zoning); the probability one (the methods of the factors' estimation of the environmental risks on the basis of the probability of the landscape's refusal to fulfill the set functions), elaborated by M. D. Grodzynsky [44, 45]: 1 - the estimation's methods of indicators, according to the frequency of the events (refusals, restorations, the transition between the states' spheres), 2 - the methods of estimation, according to the function of the incidental values' distribution (time of the refusal's appearance or the restoration of the landscape), 3 - methods of estimation, according to the variation of the indicators in the limits of the set range.

\section{Results}

The territory of Kryvyi Rih belongs to the steppe landscape's zone. It's determined by the research on the basis of the functional analysis of the town that the industrial zone consists mainly of over 100 enterprises of the mining-extractive (mines, carriers, the area is 33 sq.km), processing and metallurgical branches (5 mining-dressing combines, the metallurgical combine "ArcelorMittal Kryvyi Rih", a series of the machinebuilding and processing plants); the residential area - is represented by the low-building's and tall-building's residential areas, the cottage settlements; the agricultural one - by the arable lands of different specialization, the pasture-grounds and the garden landscapes; the water farming - by the rivers, storage reservoirs, the irrigating and arterial canals, lakes; the travelling-transport one by the railways and automobile roads of different categories, the garage and station complexes; the environment-creating one - by the forestry complexes, parks, squares and the objects of the natural-protected land fund (the landscape areas of the general-state meaning - the "Ingulets steppe" and the "Balka Pivnichna Chervona"); the zone of the marching complexes is represented by the various destructive landscapes and the waste grounds.

The industrial, residential and agricultural landscapes dominate in the territorial structure of the town. The difficult interaction of nature and economy leads to the formation of the different anthropogenic and anthropogenically modified landscapes, but putting of the anthropogenic processes over the natural ones leads to the formation of the ecological situations and creates the pre-conditions for the active display of various types of the environmental risk, the estimation's results of which are presented lower. 
The risk's estimation of the atmospheric air pollution showed that nearly $90 \%$ landscapes of Kryvyi Rih are characterized by the levels of probability of occurrence $0,7-1$, including the residential, environment-creating, water farming zones and the suburban complexes; $10 \%$ - by the probability level of $0,2-0,7$. The hydrogeological risks have the very high probability of occurrence (it's displayed in all the water landscapes of the town and was equal to 0,7-1). The probabilities among the hydro-geological risks were estimated in such a way: the indicator of the contamination of the underground waters varies in the limits of $0,2-1$, however, $85 \%$ of the territory are estimated by the high probability $(0,4-0,7)$; nearly $6 \%$ - by the very high one $(0,7-1) ; 9 \%$ - are coincided with the exploitation of the deposit - not estimated; the probability of the flooding varies from 0 to 1 and displayed only on $30 \%$ of the territory, occupied by the different hydro technical structures; the risk of the appearance of floating sands and change of big rivers and silting of rivers is presented locally (they are estimated qualitatively as they were spread on the very limited territory of the region). The geological-geo-morphological risks are estimated, according to the four types: the risk of the gravitational processes is represented by the landslides $(0,03-0,18)$ and crumbles (it's revealed on the sides of dumps and carriers, the probability - 1); the risk probability of the formation of fissures and cracks of the land surface above the mine excavations equals $0,02-0,75$, but the risk probability of crashes $-0,013-0,25$.

The risk of activation of the karst-suffosium processes is estimated by the average and not high meanings of the probabilities $(0,2-0,5)$, it affects the functioning of some types of the landscapes - the residential, agricultural and park ones. The risk of the activation of the tectonic processes is important $(0,5-$ $0,75)$, according to the possible results of its display.

The ground risks are estimated by 4 types: the risk of the grounds' contamination by the chemical substances has the extreme and very high probability $(0,7-1)$ per $50 \%$ of the town area; the risk of the grounds' water logging - not high, but for the separate kinds of the landscapes (especially for the suffosium and the waterdividing valleys, raving and sloping ones) - essential; the risk of the grounds' salting is lighted up by the not high levels of the probability and has the territorial connection with the risks of the water logging and flooding; the risk of the acidity level's change of the grounds is developed in the same types of the landscapes as the two previous ones and has mainly the low levels of the probability's display, except the landscapes of the suffosium valleys [20].

The risk of display of the exotic-genetic geological processes is estimated for $30-45 \%$ of the landscapes' types as the high one (used intensively by the person).

The integral indicator's estimation of the environmental risk probability showed that it is formed on the territory of Kryvyi Rih by 17 types of the risks, being estimated above, but not all of them have the urgent importance in the creation of this indicator's high probability, therefore the analysis was made on the basis of the selection of those types of the landscapes, where the equal probabilities of the separate types of risk were above 0,7 . It's stated that the number of risks with the high level of probability $(\geq 0,7)$, those ones that urgently cause the high integral indicator, lie in the limits 1-5. The map is made, according to the results of the conducted estimation and on the basis of the component analysis of the risk. The analysis showed that nearly $65 \%$ of the territory experienced the one- and the twocomponents risk, the significant role here was played by the risk of pollution of the atmospheric air, the surface and the underground waters, the rest one $-35 \%-$ experienced the risk, according to the 3,4 , and 5 types of the environmental risk. All the residential tall buildings' and some low buildings', the industrial and destructive, some agricultural and the environment-creating types of the landscapes have the high level of the multicomponents' environmental risk. 11 electronic maps of the environmental risks were made for Kryvyi Rih, according to the estimation's results, with the help of the GIS-technologies and Corel draw.

It's determined that the biggest influence on the appearance of the ecologically-dependent diseases is made mainly by the pollution of the atmospheric air, the surface and underground waters, the contamination of the grounds; the special role is played by the probability of the untimely death of the population, due to the various socio-techno-genetic factors, but you shouldn't ignore such a fact that all the complex of the investigated factors of the environmental risk affect the population's state of health and sick rate, because they are in the whole forming the environment's quality of human life and are closely connected with each other.

The authors understand the environmental risk as the probability of the disease's appearance of the person, living or working in the limits of the definite landscapes. The estimation of the environmental risks is made by the authors on the basis of the comparative research of 17 types of risks (the environmental risks, described above) and the indicators of Kryvyi Rih population's sick rate for the period of 2004-2019, and also on the basis of the statistical models' construction of spatial distribution of the effects of environmental pollution on the population's sick rate, dealing with the ecologicallydependent diseases.

The gained data of the environmental risks' estimation testify that the highest indicators of the general sick rate of the population are characteristic for such regions of the town as the Pokrovsky, Saksagansky, the Central-Municipal ones, on the territory of which nearly 50 industrial enterprises are situated, they are mainly the acting mines, carriers and the dumps of the mining-ore-dressing combines and the combines themselves, the full-cycle metallurgical combine "ArcelorMittal Kryvyi Rih". The comparison of the data of the population's general sick rate with the maps of the risk of the town's atmospheric air pollution shows that the territory of the Saksagansky and the CentralMunicipal regions coincides with the territory of the mostly polluted air. The lowest indicators of the population's general sick rate are characteristic for the Ternivsky and Inguletsky regions (these are the most northern and the most southern regions of the town), and 
if the air pollution's indicators are not high in the Ternivsky region (1-5 of LAC, -the Limiting Admissible Concentration), then, the territory of the Inguletsky region is characterized by the high enough indicators of the pollution (5-15 of LAC). Such situation is explained by the fact that the data of the population's sick rate are collected at the separate remedial-preventive establishments, besides, the balance-wheel migrations of the population also play their roles in the middle of the town and the individual indicators of health (the influence of the genetic, social, moral and other factors).

The analysis of the population's sick rate of Kryvyi Rih for the researching period, according to the groups of diseases, shows that the greatest number of the sick rates of both among the adult population and the children's one is referred to the group of the bloodcirculation diseases (point 8 on the graph: Fig. 1,2) and the diseases of the respiratory organs (point 10 on the graph: Fig. 1, 2), the urinary-sexual system's diseases play a bit less role (point 15 on the graph: Fig. 1,2) and other diseases (Fig. 1, 2)

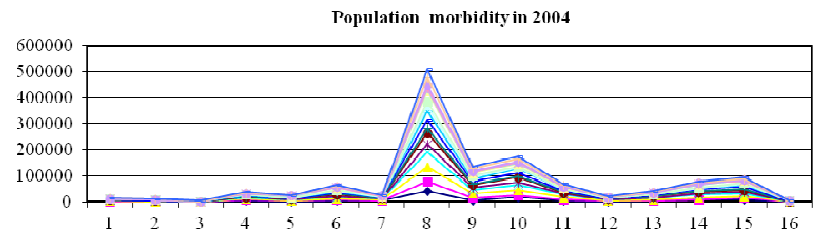

Fig. 1. The sick rate of Kryvyi Rih population for 2004.

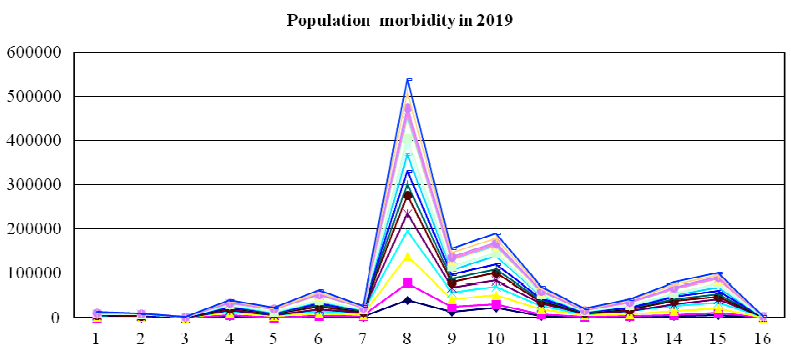

Fig. 2. The sick rate of Kryvyi Rih population for 2019.

The conventional symbols: 1 - some infectious and parasitical diseases, 2 - neoplasms, 3 - diseases of blood, the blood-creating organs, 4 - diseases of endocrine systems, 5 - diseases of nervous system, $6-$ eye diseases, 7 - ear diseases, 8 - diseases of blood circulation system, 9 - heart diseases, 10 - diseases of respiratory organs, 11 - diseases of digestion organs, 12 - liver diseases, 13 - skin diseases, 14 - diseases of osseous and muscular system, 15 - diseases of urinary and sexual system, 16 -diseases of milk gland. The total number of diseases at the hospitals is indicated on the graph by the lines.

The research of the spatial distribution's influence of the contamination's sources on the population's sick rate and the gained data of the environmental risk's estimation was conducted, according to the methods of the statistical modelling (the regressive analysis) and with the help of GIS MapInfo Professional. A series of maps of the population's sick rate of Kryvyi Rih town, dealing with the different groups of diseases, was constructed by the authors on the basis of the conducted analysis; the maps of the sick rates with the system's diseases of the blood circulation and the respiratory organs are presented on the figures 3, 4. The constructed maps and the estimated environmental risks visualize and confirm the dependence between the contamination and the sick rate of the population, characterize the sick rate of the population, dealing with the separate diseases.

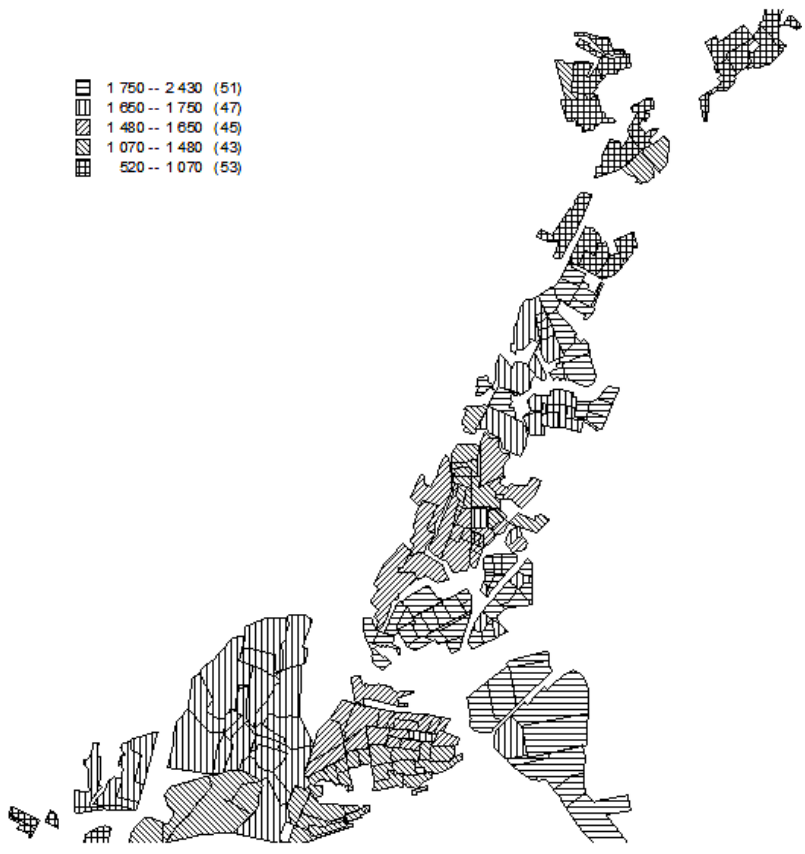

Fig 3. Circulatory system's morbidity data 2019.

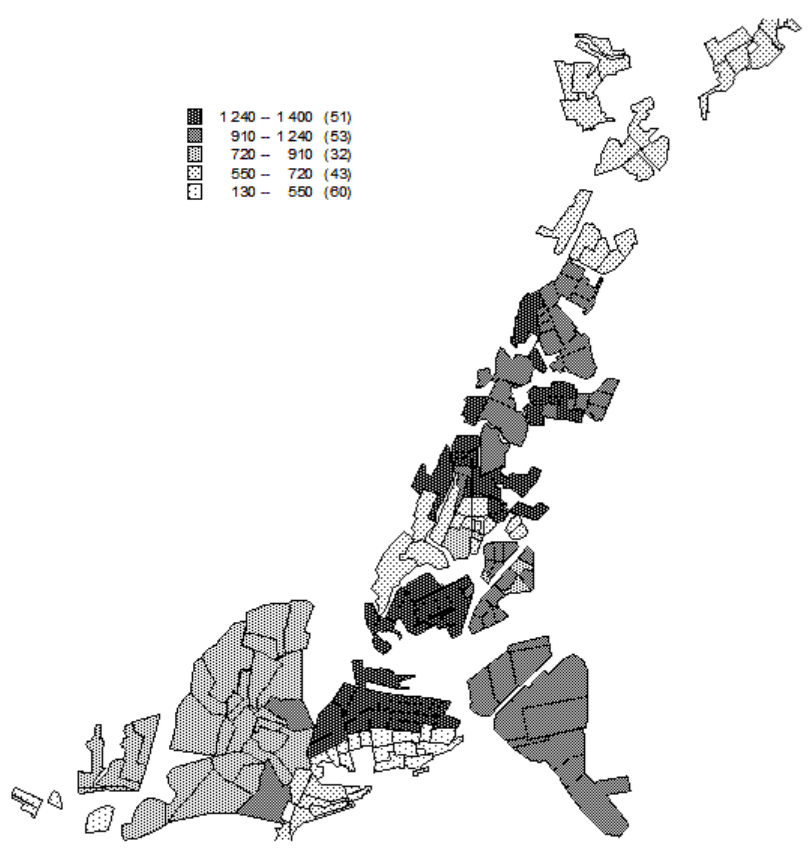

Fig 4. Respiratory system's morbidity data 2019.

In order to construct the regressive models, the authors fulfilled the non-linear analysis for the main groups of the ecologically-dependent diseases for the period of 2004-2019. It's cleared up, that the biggest determination from the quality of the atmospheric air is observed for the diseases of the blood circulation system (the coefficient of the determination is $0,43-0,49$ ), the 
diseases of the respiratory organs (the coefficient of the determination is $0,3-0,5$ ).

Some graphics of the regressive disease's dependence of the blood circulation system and the respiratory organs on the distance to stationary sources of pollution in 2004, 2019 are presented lower (Fig. 5, 6, $7,8)$.

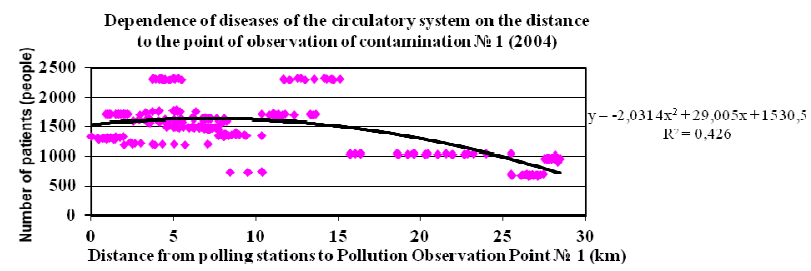

Fig. 5. Regressive model of blood-circulation's disease dependence on distance to stationary sources of pollution (2004).

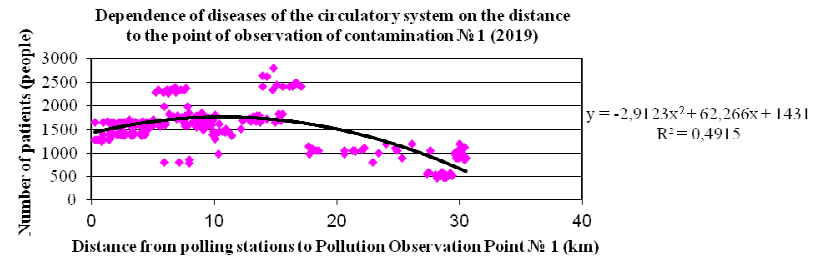

Fig. 6. Regressive model of blood-circulation's disease dependence on distance to stationary sources of pollution (2019).

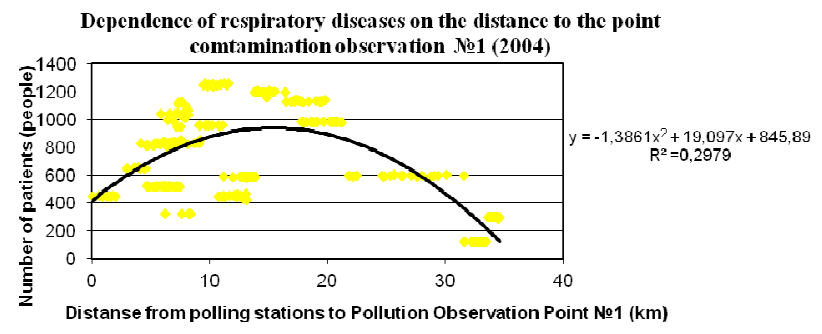

Fig. 7. Regressive model of respiratory organs' disease dependence on distance to stationary sources of pollution (2004).

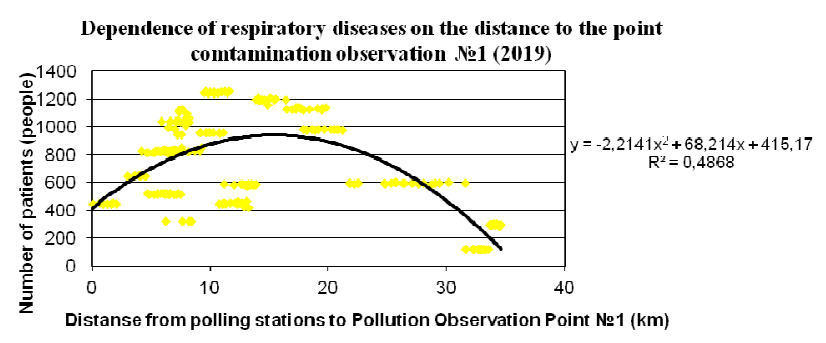

Fig. 8. Regressive model of respiratory organs' disease dependence on distance to stationary sources of pollution (2019).

The analysis of the constructed regressive models (Fig. 5-8) proves that the dependence of the sick rate with the definite groups of diseases on the ecological factors, in particular, the state of the atmosphere, is important. In most cases it is described exactly enough by the polynomial of the second degree with the meaningful coefficients of the determination. The regressive models, presented above, represent the dependence of the population's sick rate on the state of the air basin in the generalized form. The conditional dependence's stability of the definite diseases on the environment's conditions is also confirmed by the statistical analysis on the construction's basis of the model of the spatial distribution of the contamination's influence on the population's sick rate.

Taking into account the results of the investigations and the results of the expert estimations [46, 47], the grouping of the diseases, according to the degree of the different factors' influence on the process of their appearance, was made and the stable interconnection and the dependence of the disease's display on the environment's state of human life is determined (Table 1).

Table 1. Distribution of separate components into creation of ecologically-dependent diseases.

\begin{tabular}{|c|l|c|c|c|c|}
\hline \multirow{2}{*}{ Diseases } & \multicolumn{4}{|c|}{$\begin{array}{r}\text { Contribution of separate } \\
\text { components }\end{array}$} \\
\cline { 2 - 6 } & ecological & social & genotype & industrial \\
\hline 1 & $\begin{array}{l}\text { Some infectious and } \\
\text { parasitical diseases }\end{array}$ & ++ & +++ & ++ & + \\
\hline 2 & Neoplasms & +++ & - & ++ & ++ \\
\hline 3 & $\begin{array}{l}\text { Diseases of blood, } \\
\text { blood-creating } \\
\text { organs }\end{array}$ & ++ & + & +++ & + \\
\hline 4 & $\begin{array}{l}\text { Diseases of } \\
\text { endocrine system }\end{array}$ & +++ & ++ & ++ & + \\
\hline 5 & $\begin{array}{l}\text { Diseases of nervous } \\
\text { system }\end{array}$ & - & ++ & + & + \\
\hline 6 & $\begin{array}{l}\text { Diseases of eye and } \\
\text { adventive system }\end{array}$ & ++ & + & ++ & ++ \\
\hline 7 & $\begin{array}{l}\text { Diseases of ear and } \\
\text { comforter-type } \\
\text { appendix }\end{array}$ & - & + & + & ++ \\
\hline 8 & $\begin{array}{l}\text { Diseases of blood } \\
\text { circulation system }\end{array}$ & ++ & + & ++ & ++ \\
\hline 9 & Heart diseases & ++ & ++ & ++ & +++ \\
\hline 10 & $\begin{array}{l}\text { Diseases of } \\
\text { respiratory organs }\end{array}$ & +++ & ++ & ++ & +++ \\
\hline 11 & $\begin{array}{l}\text { Diseases of } \\
\text { digestion organs }\end{array}$ & +++ & +++ & ++ & +++ \\
\hline 12 & Liver diseases & ++ & ++ & ++ & + \\
\hline 13 & $\begin{array}{l}\text { Diseases of skin and } \\
\text { hypodermic } \\
\text { cellulose }\end{array}$ & +++ & ++ & + & ++ \\
\hline 14 & $\begin{array}{l}\text { Diseases of osseo- } \\
\text { us-muscular system }\end{array}$ & +++ & ++ & ++ & ++ \\
\hline 15 & $\begin{array}{l}\text { Diseases of urinary- } \\
\text { sexual system }\end{array}$ & +++ & + & + & ++ \\
\hline 16 & $\begin{array}{l}\text { diseases of milk } \\
\text { Gland }\end{array}$ & +++ & ++ & + & + \\
\hline
\end{tabular}

The peculiarities of the environmental risks' display, the character of the population's sick rate distribution, the display of the most number of the diseases of the separate groups (blood circulation system and respiratory organs), determined by the authors, may influence the indicators of the birth-rate, mortality and the natural increase of population.

The distribution of the dead people's quantity for the separate reasons of death throughout Kryvyi Rih town 
(Fig. 9) shows that the first place is occupied by the diseases of the blood circulation system $(67 \%)$, the second one - the oncological diseases $(12 \%)$, the third one - the diseases of the respiratory organs $(3 \%)$ and other diseases.

The number of Kryvyi Rih population was reducing during the research period (2004-2019). It was caused by the small number of the new-born children, not exceeding the number of the dead people, and the negative balance of the migration from 2007. The population is getting old, due to the growth of the average duration of life and the small quantity of the new-born children. The part of the young people reduces, but the part of the elderly people grows. From 2004 to 2019, the coefficients of the birth-rate (the average number of children, born by the averagestatistical woman during the life) grew constantly: from the indicator of 0,97 of a child for a woman in 2004 till 1,32 of a child for a woman in 2019 , the summary coefficient of the birth-rate doesn't achieve the level of the natural replacement, being equal to 2,1 - it means that the number of the town population will be less, if the migration balance is left negative.

The number of the population reduced, first of all, due to the constantly high coefficient of mortality among the elderly people. Besides, the small quantity of the new-born children and the flow of the population back didn't give any opportunity to compensate the indicator of mortality. The migration's flow of the population back, which started in 2007, was caused by the optimization of the personnel's number at the powerful enterprises of the town, especially by the introduction of the programs, concerning the personnel's dismissal, according to their own wish, from the PJSS "ArcelorMittal Kryvyi Rih". At the same time, the tendency, concerning the reduction of the migration's upsurge of the population, was observed.

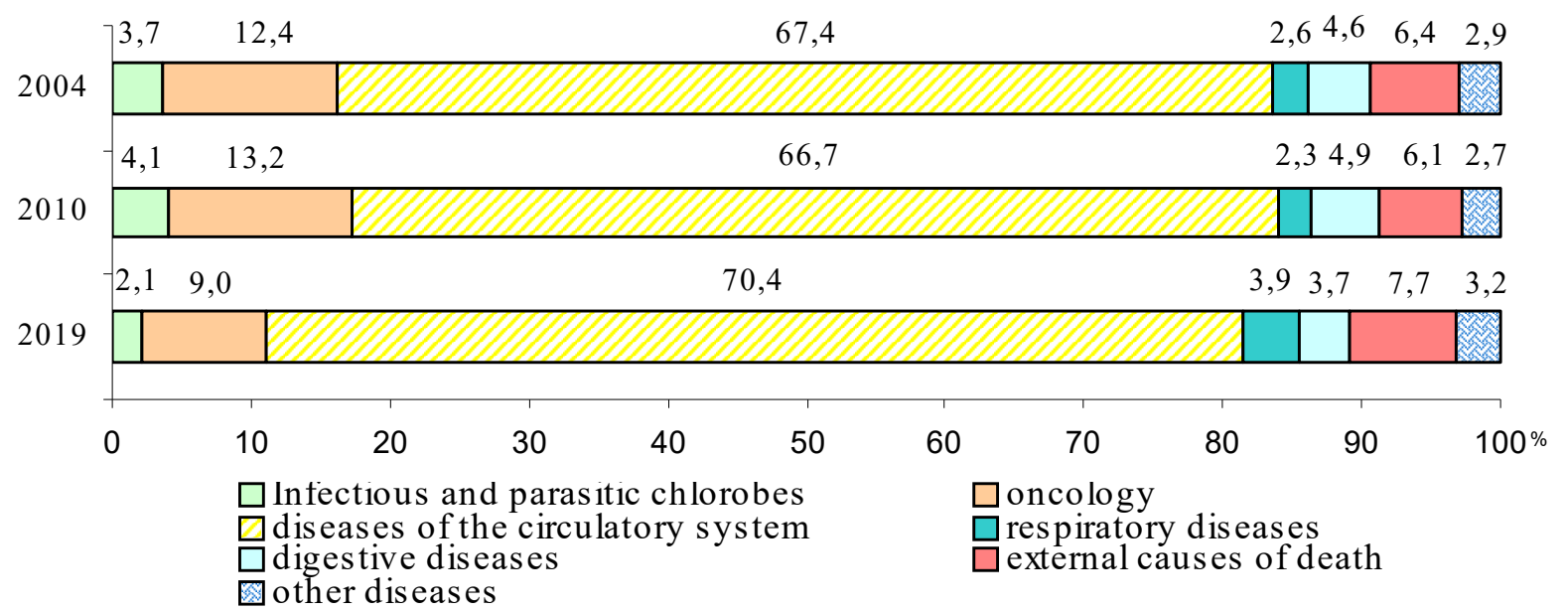

Fig. 9. Distribution of dead people's quantity in time cuts for separate reasons of death.

\section{Conclusions}

The scientific results of the research have the special methodical and practical value for the realization of the similar scientific investigations in the other industrial regions.

The conducted analysis and estimations are the methodic and practical basis for the realization of the Kryvyi Rih strategic development, particularly, in the parts of the territorial planning of the town, the organization of health protection, the ecological monitoring of the territory, the statistical data base and others. The cartographical, ecological, medical data, being gained in the research, are used by the statistical department of Kryvyi Rih town, the department of health protection of the municipal executive committee of Kryvyi Rih, the ecological department, the ecological inspection, the department of architecture and planning and also the Institute of the town's development.

The complex of the events [20], being oriented at the minimization of the environmental risks, being realized via the landscape- and territorial-planning, the environment-creating events, are elaborated. The research results are taken into account in the project of creation of the Kryvbas ecological net, the organization of the sanitary-protective and water-safeguarding zones of the rivers and water reservoirs, the buffer zones of the nature-protection objects, the suburban zones of the town.

The results and the regularities of the formation of the ecologically-dependent diseases, the medicalgeographic zoning of Kryvyi Rih territory may serve as the ecological criterion of the environment's quality of human life and be correspondingly used by the local population for the selection of the place of the residential premises' location in the limits of Kryvyi Rih town. Besides, the knowledge of the ecological situation of the definite region may be one of the criteria of the formation of the cost and price of the residential premises (rent or purchase) and the basis for the creation of the so-called "ecological rent".

The expressed positions of the article are used in the scientific and training processes at teaching of the disciplines of the ecological, geographical and cartographical direction at the Kryvyi Rih State Pedagogical University. 
Thus, the research, conducted by the authors, is directed at the provision of the stable development of Kryvyi Rih, in which there are:

1) the rational and complex use of natural conditions and resources of the Kryvyi Rih basin of iron ores;

2) the healthy qualified environment of population life;

3 ) the influence's minimization on natural components (requires the diligent research in the perspective).

The geographic research of the ecologicallydependent diseases of Kryvyi Rih population showed that the display and the consequences of such sick rates have the double character: from one side, they are caused by the ecological situation of the region and are the display's result of the ecological factors of different genesis (the pollution of the atmosphere, the surface waters, grounds and others), from the other side, they are the expression of the environmental risks of separate type and in such case it's the probability of the disease's appearance for the person, living in the limits of the definite town.

The conducted analytical, statistical, graphical and the cartographical researches confirmed the position on the fact that the original environment of the population life is being formed in Kryvyi Rih town (with its specific configuration, socio-economic peculiarities, economic specialization in the spheres of the extractive and processing industry). The display's peculiarities of the separate types of the environmental risks, which appeared to be high and extremely high in the limits of the researched town, are determined by the authors. It's cleared up that all the residential tall buildings and some low buildings, the industrial and destructive, some agricultural and environment-creating types of the landscapes have the high level of the multi-component's environmental risk, - thus, the town territory is characterized by the extremely low environment's quality of human life.

The formation's peculiarities of the ecologicallydependent diseases and their space-time dependences are determined. Such comparisons of the space-time regularities of the display of the environmental risks and indicators of the population's sick rate showed that the maximal risk to get the disease is characteristic for the people, who live in the limits of the terrace tall landscapes $(0,90)$, and $a$ little bit less - in the limits of the flood-landed, low, the terrace low, the erosive-ravine and powerful tall and low buildings, near the waterdividing valley tall buildings' landscapes $(0,71-0,78)$, the lowest probability of risk is defined for the waterdividing valley low buildings' types of the landscapes $(0,54)$. The analysis of the population's sick rate, according to the group of diseases, showed that the greatest number of the population's sick rate both among the adult population and among the children's population is referred to the group of the diseases of the blood circulation system, the respiratory organs, the other diseases play a bit less role. These data are confirmed by the constructed statistical regressive models - the dependence of the sick rate with the definite groups of diseases on the ecological factors is revealed, in particular, the atmosphere state, the regressive dependence of the sick rate of the blood circulation system and the respiratory organs on the distance to the stationary sources of pollution.

It's stated on the basis of the analysis of the main demographic indicators and the indicators of the population's sick rate of Kryvyi Rih that the sick rate and the mortality, caused by it, play the essential role in the development of the demographic situation.

Thus, the authors confirmed the supposition on the fact that the display of the ecologically-dependent diseases in the industrial towns is constantly connected, in the first turn, with the high levels of the pollution's probability of the atmospheric air, the surface and underground waters, grounds; the indicators' dependence of the birth-rate, mortality and the natural increase of the town's population on the high level of the probability of the environmental risk's display is cleared up.

It's determined that the very complex geographic researches of the population's sick rate acquire more and more importance on conditions of the stable development's provision of the industrial cities and towns.

\section{References}

1. E.N. Pavlovsky, Prirodnaya ochagovost transmissivnyih bolezney $v$ svyazi s landshaftnoy epidemiologiey zooantroponozov (Natural foci of vector-borne diseases in connection with the landscape epidemiology of zooanthroponoses). (Nauka. Leningradskoe otdelenie, MoscowLeningrad, 1964)

2. E.L. Reich, Modelirovanie v meditsinskoy geografii (Modeling in Medical Geography). (Nauka, Moscow, 1984)

3. A.A. Keller, O.P. Shchepina, A.V. Chaklin, Rukovodstvo po meditsinskoy geografii (Guide to Medical Geography). (Gippokrat, St. Petersburg, 1993)

4. A.G. Voronov, Biogeografiya (s elementami biologii) (Biogeography (with elements of biology)). (Izdatelstvo MGU, Moscow, 1963)

5. E.V. Rothschild, Prostranstvennaya struktura prirodnogo ochaga chumyi i metodyi ee izuchenie (The spatial structure of the natural focus of the plague and methods for its study). (MGU imeni M. V. Lomonosova, Moscow, 1978)

6. I.V. Martusenko, Dissertation, Kyivskyi natsionalnyi un-t im. Tarasa Shevchenka, Kiev, 2005

7. N.I. Mezentseva, S.P. Batichenko, Economic and social geography $\mathbf{6 5}, 45-52$ (2012)

8. L.M. Nemets, Medychna haluz Kharkivskoi oblasti: terytorialni osoblyvosti, problemy ta shliakhy vdoskonalennia (suspilno-heohrafichni aspekty) (Medical sector of Kharkiv region: territorial features, problems and ways of improvement (sociogeographical aspects). (Chetverta khvylia, Kharkiv, 2009) 
9. B.B. Prokhorov, Mediko-ekologicheskoe rayonirovanie $i$ regionalnyiy prognoz zdorovya naseleniya Rossii (Mediko-ecological zoning and the regional forecast of health of the population of Russia). (Izd-vo MNEPU, Moscow, 1996)

10. I.Yu. Filimonova, Meditsinskaya geografiya i kurortologiya (Medical geography and balneology). (IPK Gazprompechat, Orenburg, 2009)

11. V.O. Shevchenko, Tsentryzm ta tsentrychnist $v$ heohrafii (Centrism and centricity in geography). (Nika-tsentr, Kiev, 2006)

12. P.Ya. Baklanov, Strukturizatsiya geograficheskogo prostranstva - osnova teoreticheskoy geografii (Structurization of geographical space - the basis of theoretical geography). Paper presented International Scientific Conference Theory of socioeconomic geography: current status and development prospect, Izd-vo YuFU, Rostov-onDon, 4-8 May 2010

13. S.P. Sonko, D.V. Shiyan, Human Geography Journal 18, 63-70 (2015)

14. C.M. Malkhazova, E.G. Koroleva, Okruzhayushaya sreda $i$ zdorove (Environment and Health). (Geograficheskij fakultet MGU, Moscow, 2009)

15. World Health Organization Regional Office for Europe, European Health for All database (HFADB) (2019),

https:/gateway.euro.who.int/en/datasets/europeanhealth-for-all-database/. Accessed 31 Mar 2020

16. P.P. Calow, Handbook of Environmental Risk Assessment and Management (Blackwell Publishing Ltd., Sheffield, 1998)

17. S.A. Kurolap, Meditsinskaya geografiya: sovremennyie aspektyi (Medical geography: modern aspects). Soros Educational Journal in text format. Earth sciences (2000), http://www.pereplet.ru/obrazovanie/stsoros/1036.ht $\mathrm{ml}$. Accessed 31 Mar 2020

18. Z.V. Gerasymchuk, V.G. Polishchuk, Stymuliuvannia staloho rozvytku rehionu: teoriia, metodolohiia, praktyka (Stimulating the sustainable development of the region: theory, methodology, practice). (Luckij nacionalnij tehnichnij universitet, Lutsk, 2011)

19. J.H. Hulse, Sustainable Development at Risk: Ignoring the Past (International Development Research Center, Ottawa, 2007)

20. I.O. Ostapchuk, Dissertation, Tavricheskij nacionalnyj universitet imeni V. I. Vernadskogo, Simferopol, 2010

21. World Health Organization, Global Health Estimates 2016: Disease burden by Cause, Age, Sex, by Country and by Region, 2000-2016 (World Health Organization, Geneva, 2018), http://www.who.int/healthinfo/global_burden_diseas e/estimates/en/index 1.html. Accessed 31 Mar 2020

22. Australian Institute of Health and Welfare. Risk factors to health (2017), https://www.aihw.gov.au/reports/biomedical-riskfactors/risk-factors-to-health/contents/risk-factorsand-disease-burden. Accessed 31 Mar 2020

23. E.N. Pavlovsky, Metodyi $i$ zadachi meditsinskoy geografii (Methods and tasks of medical geography), in Collection of articles for the XVIII International Geographical Congress (Izd. Akademii nauk SSSR, Moscow-Leningrad, 1956)

24. A.A. Shoshin, Osnovyi meditsinskoy geografii (Fundamentals of medical geography). (Izd. Akademii nauk SSSR, Moscow-Leningrad, 1962)

25. V.M. Gutsulyak, Medichna geografIya: EkologIchniy aspect (Medical Geography: Ecological Aspect). (Ruta, Chernivtsi, 1997)

26. N.P. Ponomarenko, S.I. Garkavy, M.M. Korshun, M.Yu. Antomonov, Environment and Health 4, 30 36 (2015)

27. G.G. Shmatkov, A.F. Oxamytny, I.N. Nikolaeva, J. Ecology and nature management 12, 42-47 (2009)

28. S.P. Sonko, Prostorovyi rozvytok sotsio-pryrodnykh system: shliakh do novoi paradyhmy (Spatial development of socio-natural systems: the path to a new paradigm). (Nika Tsentr, Kiev, 2003)

29. I.D. Bagrii, P.V. Blinov, Y.G. Vilkul, Y.D. Mayakov, Dosvid kompleksnoi otsinky ta kartohrafuvannia faktoriv tekhnohennoho vplyvu na pryrodne seredovyshche mist Kryvoho Rohu ta Dniprodzerzhynsk. (Experience of complex assessment and mapping of factors of technogenic impact on the natural environment of the cities of Kryvyi Rih and Dneprodzerzhinsk). (Feniks, Kiev, 2000)

30. I.A. Manaenkova, in Heohrafiia v informatsiinomu suspilstvi (Geography in the information society), vol. 2 (VHL Obrii, Kyiv, 2008), pp. 286-287

31. L.A. Prokhorova, in Prostorovyi analiz pryrodnykh $i$ tekhnohennykh ryzykiv $v$ Ukraini (Spatial analysis of natural and technogenic risks in Ukraine), ed. by L.H. Rudenko (NAN Ukrainy. Viddilennia nauk pro Zemliu. Instytut heohrafii, Kyiv, 2009), pp. 258-262

32. V.A. Shevchenko, Mediko-geograficheskoe kartografirovanie territorii Ukrainyi (Medicalgeographical mapping of the territory of Ukraine). (Naukova dumka, Kiev, 1994)

33. L. Lupu, Quaestiones Geographicae 38(4), 5-13 (2019)

34. V.I. Fedotov, S.A. Kurolap, Regionalnaya otsenka ekologo-gigienicheskoy komfortnosti territorii $v$ sisteme sotsialno-gigienicheskogo monitoringa (Regional assessment of ecological and hygienic comfort of the territory in the system of social and hygienic monitoring). (VGU, Voronezh, 1997)

35. A.P. Algin, Risk $i$ ego rol v obschestvennoy zhizni (Risk and its role in public life). (Myisl, Moscow, 1989)

36. S.M. Malkhazova, R.S. Chalova, Geografiya, obschestvo, okruzhayuschaya sreda. T.4: Prirodnoantropogennyie protsessyi i ekologicheskiy risk 
(Geography, society, environment. Vol. 4 Natural anthropogenic processes and environmental risk). (Gorodec, Moscow, 2004)

37. D.V. Shiyan, Geography and Tourism 16, 207-217 (2011)

38. T.V. Vatlina, Environmental epidemiology and medical geography 46, 129-142 (2011)

39. S.M. Malkhazova, Mediko-geograficheskiy analiz territoriy: kartografirovanie, otsenka, prognoz (Medical-geographical analysis of territories: mapping, assessment, forecast). (Nauchnyiy mir, Moscow, 2001)

40. O.P. Gavrilenko, Ekoheohrafiia Ukrainy (Ecogeography of Ukraine). (Znannia, Kiev, 2008)

41. O.N. Litvinova, Bulletin of social hygiene and health organization of Ukraine 1, 22-25 (2001)

42. D.V. Shiyan, Bulletin of the Donetsk Institute of Social Education: Series Geography 7, 132-135 (2011)

43. X. Du, Z. Zhang, L. Dong, J. Liu, A.G.L. Borthwick, R. Liu, Acceptable Risk Analysis for Abrupt Environmental Pollution Accidents in Zhangjiakou City, China. Int. J. Environ. Res. Public Health 14(4), 443 (2017). doi:10.3390/ijerph14040443

44. M.D. Grodzinskiy, Stiikist heosystem do antropohennykh navantazhen (Stability of geosystems to anthropogenic loads). (Likei, Kiev, 1995)

45. P. Angelstam, M. Grodzynskyi, K. Andersson, R. Axelsson, M. Elbakidze, A. Khoroshev, I. Kruhlov, V. Naumov, AMBIO 42, 129-145 (2013)

46. E.N. Kutepov, V.V. Vashkova, Zh.G. Charyev, Hygiene and sanitation, 6, 13-17 (1999)

47. R.V. Rubtsov, Environment and Health, 3(42), 3943 (2007) 